\title{
Research on the Strategic Method of Logistics Supply Chain Management
}

\author{
Fengkai Xu \\ Hubei Urban Construction Vocational and Technological College, Department of Logistics Management, \\ 430205, China \\ fengkaixu84@163.com
}

Keywords: logistics; supply chain; strategy;

\begin{abstract}
According to its mission, the fundamental purpose of logistics is to contribute to the achievement of a maximum customer services in terms of efficiency. To achieve this, the logistics department and the company management must take account of the need to know the customers' requirements on service level and the ability of the firm of cater, the need to know the level of service offered by competitors and the ability of the firm, compared to the competition, to provide the level of service required by the customers [Lambert, Stock, Ellram, 1998]. The analysis of this three aspects of management allows a company to identify the weaknesses and strengths of its business as the possible opportunities and threats in the market.
\end{abstract}

\section{Introduction}

As part of efforts to achieve a more processual approach to business research in aworld of continuous change, a paradigmshift is underway, from stating terms in the form of nouns to stating them as verbs. Thus, studies talk about organizing instead of organization and strategizing instead of strategy (Weick, 1969; Whittington \& Melin, 2003). In line with this movement, research on managerial work advances the study of managing rather than management. An extensive and growing body of knowledge describes managerial work as a complex, dynamic, and situation-dependent phenomenon. Mintzberg (1973) compares managerial work to conducting an orchestra, while Carlson (1991) uses the analogy of being a puppet in a marionette theater.

By focusing on what managers do rather than what management is, one can ask what competences are necessary to do what they do. According to Luthans, Hodgetts and Rosenkrantz (1988), successful and effective managers spend far less time on traditional management activities, such as planning, decision making, and controlling, in comparison with the average manager. Instead, effective managers spend more time on networking, routine communications, and human resource management (Luthans et al., 1988). Mintzberg (2009) acknowledges this multifaceted role and presents personal, interpersonal, informational, and actional competences as appropriate attributes for a manager.

Although scholars study managerial competence extensively (Boyatzis, 2011; Chong, 2008, 2013; Collin, 1989), the topic inthe context of logistics and supply chain management (L\&SCM) is still in its infancy. This deficiency is rather surprising, since research evidence shows that L\&SCM competence has a substantial effect on business performance and financial competitiveness (Aquino \& Draper, 2008; Bowersox, Closs, Stank, \& Keller, 2000; Ellinger et al., 2011). In addition, the requisite logistics and supply chain (L\&SC) manager competences have changed in recent decades owing to profound business transformations in the field, for example, the globalization of supply chains, continued outsourcing, and the widespread adoption of lean practices (Christopher, 2012).

Considering the effect ofmanager competences on business performance in L\&SCM, as well as the scarcity of research in the field, this topic deserves a more detailed exploration.

At present many authors are speaking more often about the important role of the logistics specialist in ensuring the competitiveness of the organization. Also authors are speaking more frequently about the concept of logistics in the trade activity in goods. Although it is a term originally used for military (army on the movement and supply), and he later expanded economic activity in other areas. 
However, logistics is still interpreted in many different ways both by practitioners, specifically those carrying out economic activities (commercial or production) and by specialists, economic theorists and researchers in the field. This situation makes logistics to be misunderstood or in any case differently understood from case to case its conceptual significance.

The tendency is to consider mainly the operational component of logistics rather than the strategic one. Consequently, the interpretation of the way logistics establishes the link between production and distribution networks through its transversal component within companies is also limited and not always correct.

\section{Theoretical background}

At the same time, it must taken into account that each market or customer group is characterized by its own set of needs [Radu C, 2013]. Some markets require and pay for a high level of readiness (as short delivery times, the acceptance of higher costs). Other markets call for efficiency (costs as low as possible, despite longer delivery times). The strategy of a company in general and especially the logistics strategy, as well as the action plans to achieve its objectives, must be based on the customer's requests and the ability of the company to respond to them.

Because the logistic strategy of a company has to be based on its customers needs, the supply chain used by a company must provide the appropriate (optimal) combination between customer requests related to a promptly delivery and those related worth efficiency in the delivery of products and goods. A company whose supply-chain better meets the needs of its customers will gain market share at the expense of other companies in the market and will thus be more profitable.

Today, most researchers agree that competence is not simply a capacity or attribute of an individual, nor an attribute of a job, but the interaction between the individual and the job at hand (Collin, 1989; Ellström \& Kock, 2008; Winterton, Delamare-Le Deist, \& Stringfellow, 2006). Lindberg and Rantatalo (2015) define professional competence as "the inferred potential for desirable activity within a professional practice” (p. 565). This definition centers on the "concretemanifestation in practice" fromwhich evaluations infer qualities. These qualities range on a continuum from desirable to undesirable, generating either appeal or distance. An examplewould be a firmhandshake, which can lead one to infer the quality of integrity or of being energetic, but can also lead to an inference of cockiness or insensitivity. Thus, this definition of competence is indifferent to whether the result is efficient or successful, as long as potential for desirable activity exists.

The subjective and relational character ofmanager competencemay cause doubts about the feasibility of analyzing such competence in research. According to Collin (1989), researchers must ground their studies in concrete experience and in the recognition of the whole person, the context, and the person/context interaction and synergy. Furthermore, Collin (1989) claims the need for multiple perspectives to understand competence.

Practice theory and manager competences To improve understanding of manager competences, L\&SCM researchers need a theory that helps to explain the phenomenon. Surprisingly, researchers have not previously used practice theory to study manager competence, although practice theory provides an excellent opportunity to spotlight the concept in research. According to Nicolini (2012), practice theory offers a new way to explain social and organizational phenomena, focusing on the practice rather than the practitioner. This theory, however, does not exclusively describe what people do; this theory also includes the whole person and perspectives on body, mind, things, knowledge, discourse, structure/ process, and the agent (Reckwitz, 2002). Furthermore, practice theory includes all the dynamics, relationships, and enactments in a system, and thus, iswell able to offer powerful analytical tools for organizational research (Feldman \& Orlikowski, 2011).

\section{Types of supply chain management decisions}

The participants in a supply chain constantly take decisions that affect the way in which their activities are conducted. Each organization tries to maximize results through a combination of outsourcing, partnership and conducting its own activities. At the moment the tendency is to focus on 
key competencies outside the firm and obtaining other activities needed to run the company [Radu C, 2013]. Although each supply chain has its unique set of market demands and operating modes, problems to be solved remain the same in every situation. Therefore, in each supply chain, management and specialists in logistics need to take individual and collective decisions relating to:(1) production; (2) storage; (3) establishing production sites; (4) transport; (5) information management.

Production (1) must include production scheduling, according to factory production capacity, balancing the required work effort, quality control, equipment maintenance. Decisions will be based on the nature of the products the market requests, the required quantities and the required timeframe for delivery.

Storage (2) must used in order to inssure a "buffer" against insecurity in the supply chain. Specific decisions regard determining the size of stocks on each level of the supply chain, the size of inventories of raw materials, semi-finished and finished products, and the optimal inventory size and timing of launching a new command. All these decisions must be always based on implicit costs.

Production location setting (3) must include decisions related to the location of factories and warehouses, the establishment of locations that involve the lowest cost, i.e. to determine whether to use existing sites or build new ones. Once taken these types of decisions, the available paths for the product to reach the final consumer are determined.

Transport (4) will involve decisions about moving inventory from one location to another within a supply chain, namely the opportunity of using different modes of transport. Thus, the distribution by air transport means or by truck can be faster and reliable, but also more expensive. Water transport or train are less expensive, but usually involve a period of time and are less certain. This uncertainty may be compensated by a higher level of inventories.

Information management (5) will require from a company decisions on the establishment of the necessary information, i.e. the information provided by the company to its partners in the supply chain. Timely and accurate information ensures proper coordination and making better decisions. With high quality information, those involved have the ability to make correct decisions about the necessary production, size and location of stocks and finding better transport solutions.

The sum of all decisions at this five areas level, defines the effectiveness and efficiency of the supply chain. The way a company can act and the ways it can compete in the market heavily dependent on the efficiency and effectiveness of the supply chain.

\section{Adapting the supply chain to achieve the strategic objectives of the company}

As shown, each market or customer category is characterized by its own set of needs. The various supply chains that serve these markets must address those needs. Some markets call and pay for a high level of readiness. Other markets require that their chains to focus on efficiency. The effect of all decisions of the five areas of the supply chain will determine how well it serves the market and how profitable is that chain for its participants [Radu C, 2013].

Thus, if a company's strategy is to sell products in large quantities at a low price, supply chain must be optimized so as that obtaining and/or the distribution of products to achieve the lowest possible costs. Conversely, if a company's strategy is to respond to requests from a particular segment of the market with the competitive advantage of the high level of customer service, supply chain must be optimized to meet their needs promptly.

To adapt the supply chain to enable it to reach the strategic objectives of the company, it is necessary to (1) understand the markets served by the company, (2) defining strengths, skills that distinguish the company and its role in serving customers and (3) development of the supply chain capabilities to support the way the company acts [Radu C, 2013].

Understanding the markets served by the company (1) involves establishing the typology of own customers, the typology of the customer's clients, the type of supply chain the company is part of and the types of needs that customers have.

Regarding the types of needs that customers may have, it should be determined:

- the quantities requested by customers: those focused on timeliness and/or proximity prefer small quantities and those who want a lower price are usually buying in bulk; the delivery times requested 
by customers: residential customers in general are less willing to accept delivery delays (even if they are not necessarily long) compared to corporate customers;

- the customer-requested product categories: high-value products (that satisfy higher value needs) are required in smaller quantities than those of lower value (satisfying the primary needs);

- the delivery service level requested: complete and timely delivery or gradual deliver on longer term;

- the price accepted by the customer: customers seeking short delivery times are willing to accept higher prices;

- the pace of product innovation: customers seeking a fast pace of innovation are willing to accept higher prices for the goods but they are calling for short delivery deadlines instead.

Defining competencies and distinctive roles of the company (2) involves establishing firm position in the supply chain (as manufacturing company, as wholesale or retail distributors, as service providers etc.), setting out key skills and the main source of profit. Establishing these issues must be made carefully because the company can serve several different market segments and can be part of many supply chains. If serving multiple market segments, the company must still seek ways to benefit from its distinctive competencies.

Some parts of the supply chain can only belong to a distinctive market segment served, while others can be combined to achieve economies of scale.For example, if manufacturing is a distinctive competence of a company, it can produce a wide range of different products in the same factories. Then the various storage and transport options can be used to deliver products to different market segments.

Capacity building-delivery supply chain (3) is based on decisions made regarding five areas. Thus, through production, delivery timeliness can be achieved by building factories with large reserves of production capacity and/or using flexible manufacturing techniques that will produce a variety of products. For an even better delivery timeliness, a company can produce in several smaller plants, close to the target customers.

Efficiency through production can be obtained by using plants with very low capacity reserves, which are optimized for producing a low range of products, to reduce costs. A greater efficiency can be achieved by centralizing production in large power plants that will produce economies of scale.

Through storage, delivery timeliness can be achieved with higher inventories, for a wide range of products. An even better delivery timeliness can be obtain by storing products in multiple locations, so they are either close to their customers or available immediately. Efficiency can be achieved by reducing the size of inventories for all goods and especially for those that sell less frequently. Economies of scale can also be achieved by storing goods in a few central warehouses.

Through the production units site, delivery timeliness can be achieved by opening more outlets/retail points, physically close to the customer base (e.g., fast food restaurants).

Conversely, to get efficiency fewer locations that centralizes all activities are needed. Through transport, delivery timeliness can be achieved by the choice of means of transport that are fast and flexible (such as aviation). In turn efficiency can be gained by postponing delivery until transport means are loaded to maximum capacity. In this instance it also preferable to use cheaper means of transport (water, rail or pipeline). Transport is even more effective if it starts from a single central point and not from several different locations.

Through information, a company can achieve a high level of delivery readiness by collecting and transmitting accurate and timely data generated by operations. But when it comes to focusing on efficiency, companies should prefer less information related to fewer activities. Also, sometimes companies choose to send less information about them in order not to be exposed to the risk that those informations being used against them.

\section{Conclusion}

Company's performance in the supply chain is given by the delivery service. It must be established from the way the company responds to every order received from the customer as a result of implementing a strategy consisting of a series of specific decisions. A higher level of service requires 
those decisions to permit the firm to meet an optimal service level and a complete customer satisfaction in terms of price, time value of the invoice, goods arrived safely at their destination. The level at which an order is satisfied is a measure of the performance of the supply chain of the company and of the strategy applied by the company for its management.

\section{References}

[1] Arnould, E. J., \& Wallendorf,M. (1994). Market-oriented ethnography: interpretation building and marketing strategy formulation. Journal of Marketing Research, 31(4), 484-504.

[2] Bowersox, D. J., Closs, D. J., Stank, T. P., \& Keller, S. B. (2000). How supply chain competency leads to business success. Supply Chain Management Review, 4(4), 70-78.

[3] Boyatzis, R. E. (2011). Managerial and leadership competencies: a behavioral approach to emotional, social and cognitive intelligence. Vision: The Journal of Business Perspective, 15(2), 91-100.

[4] Bryman, A., \& Bell, E. (2011). Business research methods (3rd ed.). Oxford, UK: Oxford University Press.

[5] Carlson, S. (1991). Executive behaviour. Reprinted with contributions by Henry Mintzberg and rosemary Stewart. Uppsala, Sweden: Studia Oeconomiae Negotiorum.

[6] Chong, E. (2008). Managerial competency appraisal: a cross-cultural study of American and east Asian managers. Journal of Business Research, 61(3), 191-200.

[7] Chong, E. (2013). Managerial competencies and career advancement: a comparative study of managers in two countries. Journal of Business Research, 66(3), 345-353.

[8] Christopher, M. (2012). Managing supply chain complexity: identifying the requisite skills. Supply Chain Forum: International Journal, 13(2), 4-9.

[9] Collin, A. (1989). Manager's competence: rhetoric, reality and research. Personnel Review, 18(6), 20-25.

[10] Cottrill, K. (2010). Are you prepared for the supply chain talent crisis? MIT Center for transportation and logistics. Retrieved October, 2014, from www.Distributiongroup.com/ articles/0211mit.pdf

[11] Czarniawska, B. (2014). Why I think shadowing is the best field technique in management and organization studies. Qualitative Research in Organizations and Management: An International Journal, 9(1), 90-93.

[12] Dubois, A., \& Gadde, L. E. (2002). Systematic combining: An abductive approach to case research. Journal of Business Research, 55(7), 553-560.

[13] Ellinger, A. E., Natarajarathinam, M., Adams, F. G., Gray, B., Hofman, D., \& O'Marah, K. (2011). Supply chain management competency and firm financial success. Journal of Business Logistics, 32(3), 214-226.

[14] Ellström, P., \& Kock, H. (2008). Competence development in the workplace: Concepts, strategies and effects. Asia Pacific Education Review, 9(1), 5-20.

[15] Feldman, M. S., \& Orlikowski, W. J. (2011). Theorizing practice and practicing theory. Organization Science, 22(5), 1240-1253.

[16] Gammelgaard, B., \& Larson, P. D. (2001). Logistics skills and competencies for supply chain management. Journal of Business Logistics, 22(2), 27-50. 